\title{
Ultrafiltration of palm oil mill effluent: Effects of operational pressure and stirring speed on performance and membranes fouling
}

\author{
Khairul Faezah Md Yunos ${ }^{1^{\dagger}}$, Nurul Ain Mazlan ${ }^{1^{\dagger}}$, Mohd Nazli Mohd Naim¹, \\ Azhari Samsu Baharuddin', Abdul Rahman Hassan ${ }^{2}$ \\ ${ }^{1}$ Department of Process and Food Engineering, Faculty of Engineering, University of Putra Malaysia, 43400 UPM Serdang, Selangor, Malaysia \\ ${ }^{2}$ Department of Manufacturing Technology, Faculty of Innovative Design \& Technology, Universiti Sultan Zainal Abidin (UniSZA), Gong Badak \\ Campus, 21300 Kuala Nerus, Terengganu, Malaysia
}

\begin{abstract}
Palm oil mill effluent (POME) is the largest pollutant discharged into the rivers of Malaysia. Thus UF membrane study was conducted to investigate the effect of pressure and stirring speed on performance of POME treatment and fouling of membrane. Two types of membrane polyethersulfone (PES) and regenerated cellulose (RC) with molecular weight cut-off (MWCO) 5 and $10 \mathrm{kDa}$ were used in this study. Results showed that, as pressure increased, fouling increased however permeate quality improved, the best pressure was 1.0 bar, where the fouling was not too high and produce good permeate quality. As stirring speed increased, fouling reduced and permeate quality improved, however, when stirring speed increased from $600 \mathrm{rpm}$ to $800 \mathrm{rpm}$, there was no significant improvement on the permeate quality. Therefore, the best condition was at $1.0 \mathrm{bar}$ and $600 \mathrm{rpm}$. PES membrane with MWCO $5 \mathrm{kDa}$ showed the best permeate quality, even fouling slightly higher than RC membrane. The permeate quality obtained were analyzed in term of dissolved solid, turbidity, suspended solid, biological oxygen demand $\left(\mathrm{BOD}_{5}\right)$ and chemical oxygen demand $(\mathrm{COD})$ were $538 \mathrm{mg} / \mathrm{L}, 1.02 \mathrm{NTU},<25 \mathrm{mg} / \mathrm{L}, 27.7 \mathrm{mg} / \mathrm{L}$ and $62.8 \mathrm{mg} / \mathrm{L}$, respectively with dominant type of fouling is cake resistance. Thus, it can be concluded water reuse standard was successfully achieved in terms of $\mathrm{BOD}_{5}$ and suspended solid.
\end{abstract}

Keywords: Permeate quality, POME, Pressure, Stirring speed, Ultrafiltration

\section{Introduction}

Palm oil industry in Malaysia is growing very fast as Malaysia is one of the largest palm oil producing countries in Asia region. However, the process of palm oil extraction comprises numbers of procedures and consumed large amount of process water. It is assumed that for production of 1 tonne crude palm oil, amount of water used is 5-7.5 tonnes and half of the water used will end up as palm oil mill effluent (POME) [1-2]. Raw POME undergoes series of treatment such as biological treatment, anaerobic treatment and ponding system process before discharged to the river [3]. These current treatment based mainly on biological treatment is quite inefficient and discharged of large amount of effluent caused deterioration of water quality, consequently lead to the environmental pollution issues [4].

In the last decade, UF has become center of attention among researchers and successfully adapted in industrial process. Today, UF as a fast-growing industry, has gain vast application in food, pharmaceutical and wastewater industries [5]. There are some studies that have been conducted to evaluate the effectiveness of membrane technology in treating POME. For instance, the highest reduction of TSS, TDS, and chemical oxygen demand (COD) achieved by $\mathrm{Wu}$ et al. [6] in treating POME were 97.7\%, 88.5\%, 6.5\% and $57.0 \%$, respectively. At highest pressure $(0.8 \mathrm{MPa})$, they also successfully recovered protein and carbohydrate up to $61.4 \%$ and $76.4 \%$. The combination of pretreatment method which is coagulation/floc-
This is an Open Access article distributed under the terms of the Creative Commons Attribution Non-Commercial License (http://creativecommons.org/licenses/by-nc/3.0/) which permits unrestricted non-commercial use, distribution, and reproduction in any medium, provided the original work is properly cited.

Copyright (C) 2019 Korean Society of Environmental Engineers
Received May 15, 2018 Accepted July 27, 2018

${ }^{\dagger}$ Corresponding author

Email: kfaezah@upm.edu.my, nurulain.fst@gmail.com

Tel: +603-8946-4308 Fax: +603-8946-4440

ORCID: 0000-0001-6465-700X (Md Yunos KF) 
culation with membrane technology (UF and RO) successfully achieved almost 78\% water recovery. Azmi and Yunos [7] used palm kernel shell-based activated carbon as pre-treatment coupled with UF membrane treatment. They achieved reduction of the pollutant elements up to $90 \%$ at optimum conditions.

However, the fouling phenomenon that occurred during filtration of membrane limited the implementation of membrane in industries. These fouling phenomena can be exhibited through resistance-in-series model that include several resistances contribute to flux decline which are fouling resistance $\left(\mathrm{R}_{\mathrm{f}}\right)$, cake resistance $\left(R_{c}\right)$, pore blocking resistance $\left(R_{p}\right)$ and membrane resistance $\left(R_{m}\right)$. $R_{f}$ is the total fouling which include $R_{m}, R_{c}$ and $R_{p}$ [8]. $R_{m}$ is the membrane intrinsic resistance characterized by mainly the pore shape and size and membrane thickness, as determined during manufacturing process [9]. $\mathrm{R}_{\mathrm{c}}$ produced when large particles that cannot enter into the membrane pores and thus deposited on the membrane surface, $R_{p}$ relates to the particles that have entered the membrane and causing clogging inside the [10].

All these resistances can alter with changes in process parameters. Tansel et al. [11] analyzed fouling resistance during ultrafiltration of activated sludge using cellulosic membrane with two different modes of filtration which are submerged and crossflow. They concluded that fouling resistance of submerged membrane increased with increased in the nominal pore size. However, for crossflow modes, fouling resistances decrease as nominal pore size increase. For submerged filtration modes, membrane exhibited significant flux loss due to cake formation followed by cake compression and pore penetration especially for 10 and $30 \mathrm{kDa}$. While for cross-flow filtration modes did not exhibit significant flux loss.

Nourbakhsh et al. [12] evaluated the effect of processing parameters on fouling resistance during microfiltration of red plum and watermelon juices. They reported reversible fouling are not affected by changes in velocity, however, it could greatly reduce cake resistances, thus, decreased irreversible fouling resistance. Increased the temperature of the industry feed could reduce reversible and irreversible fouling resistance and increased trans-membrane pressure could increase cake, reversible and irreversible resistance more than $70 \%$.

$\mathrm{Na}$ and Yonggang [13] investigated the effect of process parameters on fouling on fouling resistances during ultrafiltration of humic acid. They concluded that, rapid fouling take place due to internal pore adsorption, pore blocking and fouling gel developed on the membrane. They also found that the important parameters that decided what kind of major fouling is $\mathrm{pH}$ value which they reported acid and alkali can aggravate humic acid fouling. Acid caused formation of gel layer on membrane surface and alkali accelerates the blockage of membrane hole.

Jun et al. [14] compared membrane fouling between granular sludge system and activated sludge. They found that aerobic granular sludge caused severe membrane pore blocking while activated sludge caused severe cake fouling. MF membrane showed the largest fouling layer resistance probably because of tight pore plugging by particles whose size is similar to those membrane pores.

Therefore, the aim of this paper is to study the effect of operating pressure and stirring speed for the ultrafiltration of final discharged of Sungai Tengi's Palm POME. At different pressure and stirring speed, the efficiency of the regenerated cellulose (RC) and polyethersulfone (PES) ultrafiltration membranes for POME was determined. Besides, the fouling characteristics in the aspect of fouling resistance and intensity were modeled and analyzed.

\section{Resistance-in-series Model}

Darcy's law is used to determine filtration resistance in permeate transport through porous membranes:

$$
J_{S}=\frac{\triangle P}{\mu R_{t}}
$$

Where $J$ is the permeate flux $\Delta P$ is the trans-membrane pressure (TMP), $\mu$ is the viscosity of permeate, and $R_{t}$ is the total filtration resistance. $R_{m}$ is the membrane intrinsic resistance characterized by mainly the pore size and membrane thickness as determined by manufacturing process. Membrane resistance was calculated with the following equation:

$$
R_{m}=\frac{\Delta P}{\mu J_{w}}
$$

Where $R_{m}$ is membrane resistance, $\Delta P$ is the TMP, $\mu$ is the viscosity of water and $J_{W}$ pure water flux.

$$
R_{f}=\frac{\triangle P}{\mu p J_{p}}-R_{m}
$$

$R_{f}$ is the most important because it can be reduced by proper techniques in practical application. Where $R_{f}$ is membrane fouling, $\Delta P$ is the TMP, $\mu$ is the viscosity of permeate and $J_{p}$ flux of final discharged POME at the end of filtration.

$$
\left(R_{m}+R_{p}\right)=\frac{\triangle P}{\mu J_{a}}
$$

Where $\Delta P$ is the TMP, $\mu$ is the viscosity of permeate and $J_{a}$ water flux after membrane was rinsed with distilled water and cleaned with backwash. $R_{p}$ is pore blocking resistance was calculated using equation below:

$$
R_{p}=\left(R_{m}+R_{p}\right)-R_{m}
$$

While cake resistance $\left(R_{c}\right)$ was calculated by following equation:

$$
R_{c}=R_{f}-\left(R_{m}+R_{p}\right)
$$

\section{Materials and Methods}

\subsection{Final Discharged POME}

Samples of final discharged was taken from FELDA Palm Industries Sdn Bhd, Kuala Kubu Bharu in Selangor area, the coordinates of location is $3^{\circ} 33^{\prime} 53.3^{\prime \prime N} 101^{\circ} 39^{\prime} 10.6 \mathrm{E}$. The palm mill produced oil product from palm fruit, during the process, tons of water was consumed and half of it ends up as effluent. The effluent which is raw POME was treated with biological and chemical treatment before being released to the river. Overtime, the discharged of 
the waste caused deterioration of water quality of the river and caused adverse effect to the aquatic life even though they were regularly monitored every month. Therefore, in order to overcome the issues, this study was proposed evaluate the performance of UF membrane to recycled final discharged to the plant.

The samples were preserved and stored at a temperature of less than $4^{\circ} \mathrm{C}$ to ensure that the result of the experiment was affected by microbial action due to biodegradation. The temperature of the sample was allowed to reach the room temperature during analysis and experiment. The characteristics of analysis of final discharged and quality of permeate was evaluated through parameters such as $\mathrm{pH}$, total solid, suspended solid, dissolved solid, COD, biological oxygen demand $\left(\mathrm{BOD}_{5}\right)$, and turbidity. The analytical methods were performed based on procedures given in the APHA Standard Method for the Examination of Water and Wastewater [15]. Table 1 shows the permeate quality of final discharged POME before treated with ultrafiltration membrane.

Table 1. Quality of Final Discharged

\begin{tabular}{lc}
\hline Parameter & Final discharged \\
\hline Suspended solid & 43 \\
Dissolved solid & 890 \\
COD & 170.8 \\
BOD & 97 \\
pH & 8.25 \\
Turbidity (NTU) & 17.6 \\
\hline
\end{tabular}

* All units in mg/L except $\mathrm{pH}$ and turbidity

\subsection{Membrane Characteristics}

A flat sheet RC membrane with $0.000287 \mathrm{~m}^{2}$ effective membrane area and membrane diameter $63.5 \mathrm{~mm}$ from Merck Milipore and PES with $0.000287 \mathrm{~m}^{2}$ effective membrane area and membrane diameter $63 \mathrm{~mm}$ from Sartorius were used in this study. The molecular weight cut-off (MWCO) of the membrane used were 5 and $10 \mathrm{kDa}$, respectively. These membrane were chosen because RC membranes have been shown to be low-fouling membranes in waste treatment applications and PES membranes have good thermal and chemical resistance [16, 17].

\subsection{Experimental Unit}

Ultrafiltration experiment was conducted in a stirred ultrafiltration cell (Amicon 8200) by Milipore, USA. The suspended bar impeller of $2 \mathrm{~cm}$ inside the test cell was magnetically driven by a stirrer. This device is pressurized to force liquid through the membrane while retaining and concentrating the macromolecules. The type of ultrafiltration unit was dead-end filtration. This unit was pressurized using nitrogen gas.

The beginning of the experimental run, each membrane was compacted by filtration of pure water at 2.0 bars for $30 \mathrm{~min}$ to avoid the effects of compaction process. Thereafter, pressure reduced to the desired pressure for water flux measurement. Pure water flux was taken for $45 \mathrm{~min}$ each membrane before experiment started and the volume of permeate were recorded for every 5 min. After that, $200 \mathrm{~mL}$ of final discharged POME was subjected to ultrafiltration membranes which were RC and PES with molecular weight cut off $5 \mathrm{kDa}$. There were two parameters varied in this experiment to evaluate membrane fouling and effectiveness of membrane in treating final discharged.

The effect of pressure in improving permeate quality and reducing fouling was investigated varying the pressure from 0.5, 1.0, 1.5, 2.0 bars. After that, the effect of stirring speed on reduction of dissolved solid and turbidity as well as fouling was investigated by treating the final discharged with different stirring speed of suspended impellers bars ranging from 0, 40, 600 and $800 \mathrm{rpm}$.

Experiments were repeated for each membrane and duration for each experiment was $210 \mathrm{~min}$. Volume of permeate was collected every $20 \mathrm{~min}$ to analyze for dissolved solid and turbidity. Membranes were back-washed with distilled water for $1 \mathrm{~h}$ and then, water flux after membrane fouled was collected for $45 \mathrm{~min}$ and volume recorded for every $5 \mathrm{~min}$. Pure water flux before and after experiment was needed to analyzed membrane fouling.

\subsection{Distilled Water Flux through the Fouled Membrane}

Distilled water flux $\mathrm{J}_{\mathrm{o}}$ was measured before each experiment with a clean membrane. $\mathrm{J}_{\mathrm{o}}$ is pure water flux that was taken for $45 \mathrm{~min}$ each membrane before experiment started and the volume of permeate were recorded for every $5 \mathrm{~min}$. The temperature was maintained constant at room temperature of $25^{\circ} \mathrm{C}$. $\mathrm{J}_{\mathrm{o}}$ was calculated as below:

$$
J_{o}=\frac{Q}{A}
$$

Where $Q$ is permeate or water flow rate $(\mathrm{L} / \mathrm{h})$ and $A$ is the effective filtration area $\left(\mathrm{m}^{2}\right)$ of the membrane.

After the UF with pretreated POME, the cell was emptied, rinsed briefly, refilled with distilled water and pressurized to measure the distilled water through the fouled membrane, J. Change of $\mathrm{J}_{\mathrm{o}}$ or fouling was calculated by comparing the distilled water permeability before and after the UF as shown in following equation:

$$
\text { Fouling }(\%)=\left(1-\frac{D W P_{a}}{D W P_{b}}\right) \times 100
$$

Where $D W P_{a}$ is distilled water after effluent UF $\left(\mathrm{L} / \mathrm{m}^{2} \mathrm{~h} \mathrm{MPa}\right)$ and $D W P_{b}$ distilled water before effluent UF (in $\mathrm{L} / \mathrm{m}^{2} \mathrm{~h} \mathrm{MPa}$ ).

\section{Results and Discussion}

Trans-membrane pressure gives direct impact to the membrane and feed, while stirring speed is the simulation of cross flow filtration. The effect of pressure and stirring speed were discussed in detailed in terms of flux, fouling resistance and permeate quality (dissolved solid and turbidity).

\subsection{Effect of Applied Pressure on the Performance of UF Membrane}

\subsubsection{Effect of pressure on permeates flux}

Fig. 1 shows the effect of pressure on permeate flux of two types of membrane with different MWCO. In general, it is observed that 


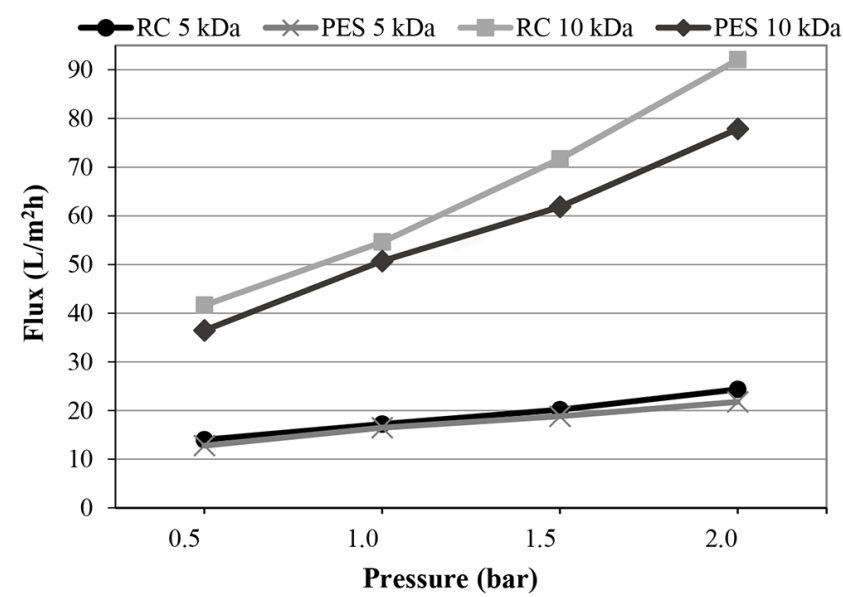

Fig. 1. Permeate flux of final discharged at different pressure.

as applied pressure increased the permeate flux increased. It could be seen that, under the same operating pressure, the permeate flux increased with increasing MWCO. From the graph, there was a slight different of flux between PES and RC membrane of same MWCO under same operation pressure, albeit the hydrophilic membrane performs slightly better in terms of permeate flux. Due to sulfonation group of PES membrane which strongly interact with the foulants, lead to adsorption on membrane surface, resulted in lower flux. Increased in pressure caused the gradual build-up of a cake layer on the membrane surface, especially at higher applied pressure, where the cake layer formed at higher pressure was denser and stable to disrupt [18]. This would cause acceleration of membrane fouling and as the membrane fouled, the permeate flux was usually difficult to stabilize [19].

\subsubsection{Effect of operating pressure on fouling}

In order to study the fouling behavior during UF of final discharged POME at different applied pressure, fouling intensity was calculated using Eq. (6) and fouling resistance was calculated based on equations in section 2. Based on Fig. 2(a) the greatest fouling intensity occurred at highest pressure of 2.0 bars for all membrane where fouling intensity of 5 and $10 \mathrm{kDa}$ PES membrane were greater than both 5 and $10 \mathrm{kDa}$ of RC membrane with fouling up to $17.90 \%$, $32.40 \%$, and RC fouling $12.95 \%$ and $28.90 \%$, respectively. At higher pressure, the formation of cake layer on membrane surface was accelerated, thus resulted in high fouling. PES membrane showed a greater fouling tendency than the RC membrane. RC membrane was less susceptible to fouling because of hydrophilicity characteristic of the polymer [16]. Besides, for both types of membrane, those with high cut-off $10 \mathrm{kDa}$ showed greater fouling than $5 \mathrm{kDa}$ membrane. These support our previous flux data, whereby higher MWCO membrane shows greater declination of flux due to tendency of foulants to be trapped inside the pores of membrane overtime lead to irreversible fouling which cannot be removed by backwashing. While smaller MWCO membrane, shows flux decline primarily due to cake formation which is reversible fouling that can be easily removed by backwash [11].

The types of fouling can be evaluated through fouling resistance which includes cake resistance and pore blocking resistance. Bar

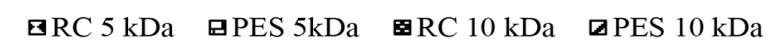
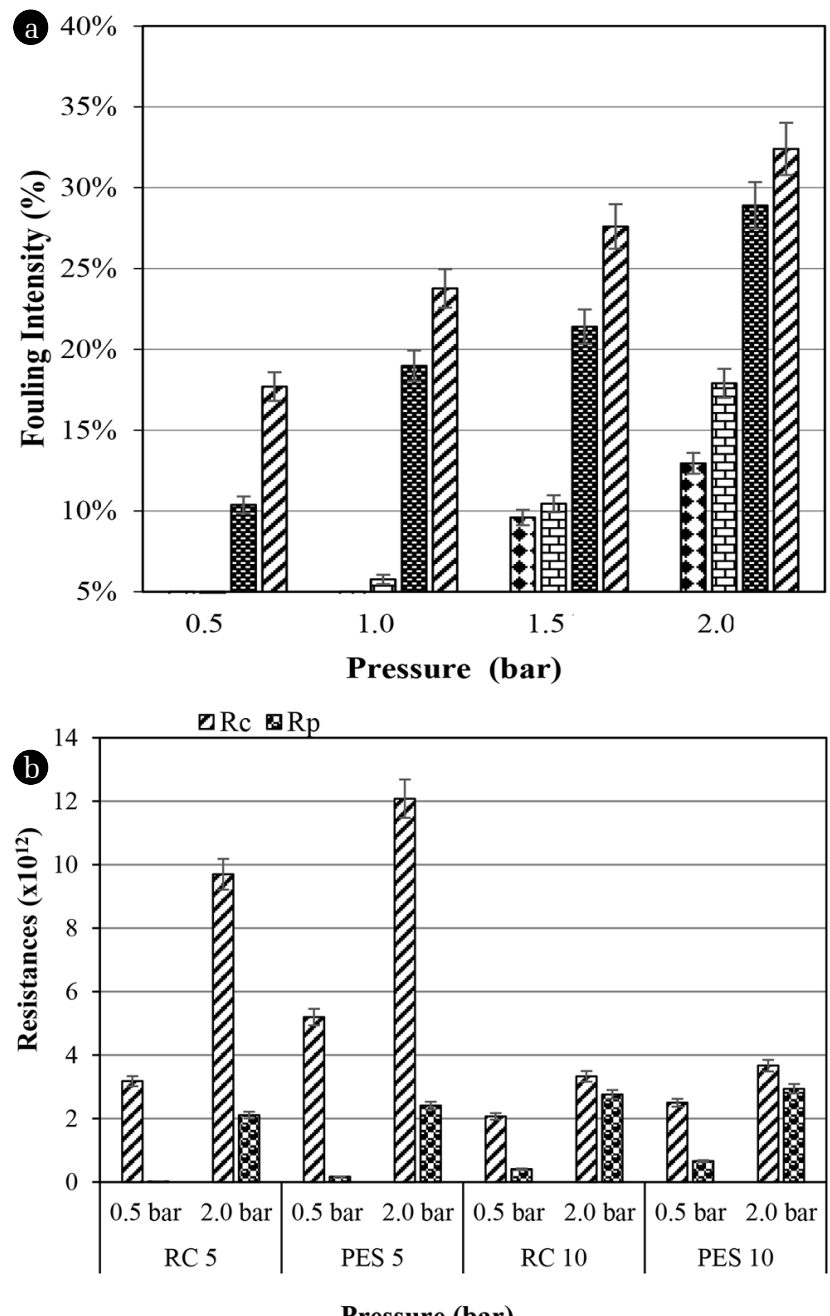

Pressure (bar)

Fig. 2. Effect of pressure on membrane fouling: (a) fouling intensity (b) fouling resistances.

chart in Fig. 2(b) showed fouling resistance at the lowest pressure and at highest pressure. For $5 \mathrm{kDa}$ membrane, cake resistance shows higher values which were $14.3 \times 10^{12} \mathrm{~m}^{-1}$ and $2.11 \times 10^{12} \mathrm{~m}^{-1}$ for PES and RC membrane, respectively, compared to pore blocking resistance values which were $0.02 \times 10^{12} \mathrm{~m}^{-1}$ and $0.17 \times 10^{12} \mathrm{~m}^{-1}$ for PES and RC membrane, respectively. This phenomenon was due to the formation of gel layer which resulted as cake layer because of the accumulation of foulant particle on membrane surface. While for $10 \mathrm{kDa}$ membrane, the graph shows that, at 2.0 bar, pore blocking resistance value are almost same as cake resistance which were $3.67 \times 10^{12} \mathrm{~m}^{-1}$ and $2.94 \times 10^{12} \mathrm{~m}^{-1}$ for PES membrane, same trend seen for RC membrane which were $3.33 \times 10^{12} \mathrm{~m}^{1}$ and $2.76 \times 10^{2} \mathrm{~m}^{-1}$, respectively. This is due to the existence of fouling layer and pore plugging which exaggerated at higher pressure and contribute to greater flux decline as previously described [6]. In a nutshell, it can be concluded that dominant types of fouling are cake resistances. This is due to the dead 
end filtration modes which induced cake formation immediately at the start of the filtration, as the pressure coming from upward of membrane pushed the feed pass through membrane cause the cake layer to build up on the surface of membrane [11].

\subsubsection{Effect of pressure on permeate quality}

Referring to Fig. 3(a), there was no significant differences of dissolved solid present in permeate of $5 \mathrm{kDa}$ and $10 \mathrm{kDa}$ membrane. Overall, total dissolved solid present in permeate were in the range between 515-530 mg/L. The same trend were observed for all membrane, as can be seen from the graph when the pressure increased from 0.5 to 2.0 bars, TDS value presence in the permeate reduced. For instance, TDS value for $5 \mathrm{kDa}$ PES and RC membrane reduced from 565 to $498 \mathrm{mg} / \mathrm{L}$ and 573 to $503 \mathrm{mg} / \mathrm{L}$, respectively. This phenomenon might be influenced by the existence of a fouling layer that developed on membrane surface and pore plugging was exaggerated at higher pressure, thus tightened the membrane and caused increased in rejection of smaller contaminants over time [2, 20]. PES $5 \mathrm{kDa}$ showed the lowest value of TDS presence, due to interaction of foulant with sulfonation group of PES membrane, lead adsorption of particle on membrane surface as well as inside the pores [6].

Turbidity has linear relationship with suspended matter in the solution. These suspended matter or particles create turbidity and impact color to the water [21]. Fig. 3(b) showed turbidity for both
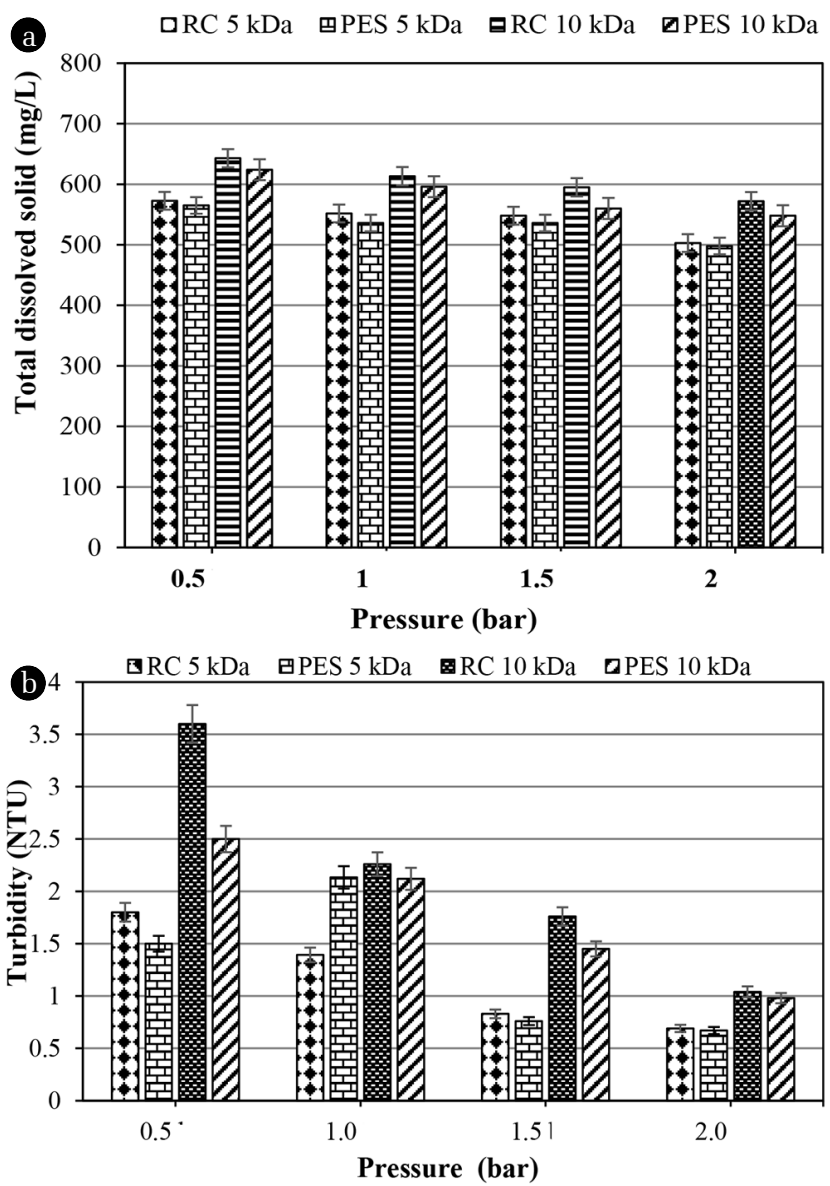

Fig. 3. Effect of pressure on (a) total dissolved solid (b) turbidity.
RC and PES membrane reduced as the pressure increased from 0.5 bars to 2.0 bars. This is pressure increased, gel layer developed on the membrane surface. This layer acts as second barrier of filtration, thus, prevent particles or any suspended matter from passing through membrane pores. The lowest turbidity was 0.69 NTU achieved by PES membrane at 2.0 bars, where rejection was 96\%. Similar phenomenon was reported turbidity of pre-treated POME reduced up to $98 \%$ at highest pressure applied. Since turbidity has linear relationship with suspended matter in the solution, the value of suspended solids content was obtained after UF membranes were below $<25 \mathrm{mg} / \mathrm{L}$.

\subsection{Effect of Stirring Speed on the Performance of UF Membrane}

\subsubsection{Effect of stirring speed on flux}

Stirring speed provide more simulation of cross-flow filtration that aim to reduce the build-up of a significant dense cake layer causing concentration polarization. Thus, variations of membrane flux during stirred flow filtration under hydraulic conditions such as shear rates were examined. Fig. 5 shows the effect of shear rates on membrane flux when stirring speed varied starting from without stirring effect to $800 \mathrm{rpm}$. As shown in Fig. 5, the fluxes increased as stirring speed increase, for example, flux of $5 \mathrm{kDa}$ RC and PES membrane increased from $14.85 \mathrm{~L} / \mathrm{m}^{2} \mathrm{~h}$ to $19.93 \mathrm{~L} / \mathrm{m}^{2} \mathrm{~h}$ and from $12.46 \mathrm{~L} / \mathrm{m}^{2} \mathrm{~h}$ to $18.76 \mathrm{~L} / \mathrm{m}^{2} \mathrm{~h}$, respectively, due to the effect of concentration polarization was minimized. Thus, all the components that accumulated on membrane surface return to the bulk of the fluid, and the concentration polarization effect diminishes [22]. However, at $600 \mathrm{rpm}$ and $800 \mathrm{rpm}$ the fluxes were almost independent of stirring conditions for both membranes tested. For example, flux of $5 \mathrm{kDa}$ PES membrane at $600 \mathrm{rpm}$ and $800 \mathrm{rpm}$ were $19.39 \mathrm{~L} / \mathrm{m}^{2} \mathrm{~h}$ and $19.93 \mathrm{~L} / \mathrm{m}^{2} \mathrm{~h}$. This phenomenon was due to relatively small cake layer resistance compared to the other resistances caused by membrane itself and fouling layers, so that the dislodging of the cake layer at higher shear rates may not show any perceptible change of flux [23]. While non-stirred conditions may increase transport resistance to the membrane surface and showed more significant fouling UF membrane filtration [24].

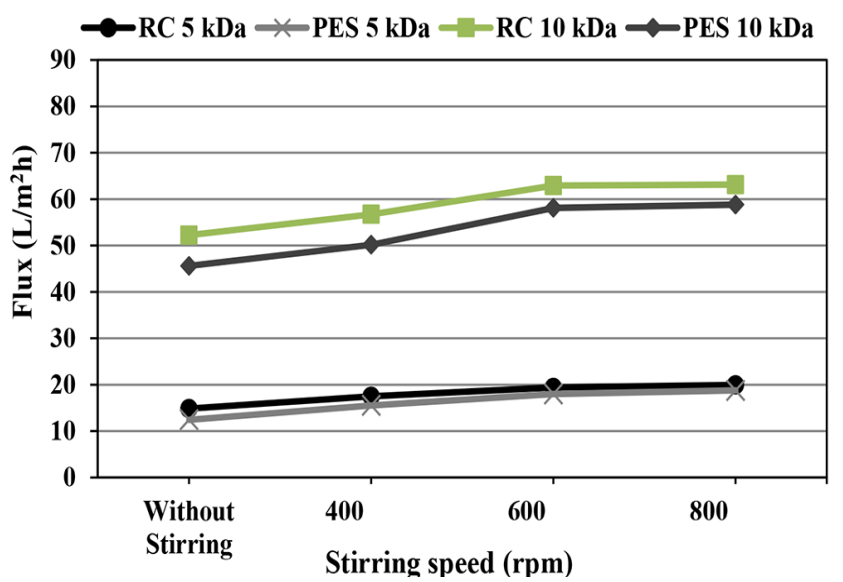

Fig. 4. Permeate flux of final discharged at different stirring speed. 


\subsubsection{Effect of stirring speed on fouling}

Fig. 5 shows the evaluation on the effect of stirring speed on fouling intensity and fouling resistance. Referring to Fig. 5(a), the highest fouling was observed during the absence of stirring effect for all membrane. As example, fouling of $5 \mathrm{kDa}$ RC, PES, and $10 \mathrm{kDa}$ RC, PES without stirring effect were $6.88 \%, 7.67 \%, 10.19 \%$, and $13.62 \%$, respectively. This result agreed with our previous findings, where non stirred conditions showed the lowest flux due to the particles in the solution transported further away from membrane surface which therefore make the foulants tend to accumulated on the membrane surface. Some of the foulants were pushed inside the pores and trapped in the pores [7]. Stirring speed increased from $400 \mathrm{rpm}$ to $800 \mathrm{rpm}$, fouling intensity reduced from $5.81 \%$ to $3.36 \%$, from $6.77 \%$ to $4.45 \%$, from $9.98 \%$ to $8.96 \%$, from 11.50 to $8.98 \%$ for $5 \mathrm{kDa}$ RC, $5 \mathrm{kDa}$ PES, $10 \mathrm{kDa}$ RC, and $10 \mathrm{kDa} \mathrm{PES}$, respectively. At stirring conditions provide more of a simulation of cross-flow filtration which reduces the build-up of a significant dense cake layer causing concentration polarization [24]

Fig. 5(b) showed the effect of stirring speed in the absence of stirring effect and at $800 \mathrm{rpm}$ on fouling resistance. It was clear that the dominant fouling resistance is cake resistance. As expected, cake resistance is the highest in the absence of stirring effect for $5 \mathrm{kDa}$ PES and RC membranes which were $11.4 \times 10^{12} \mathrm{~m}^{-1}$ and
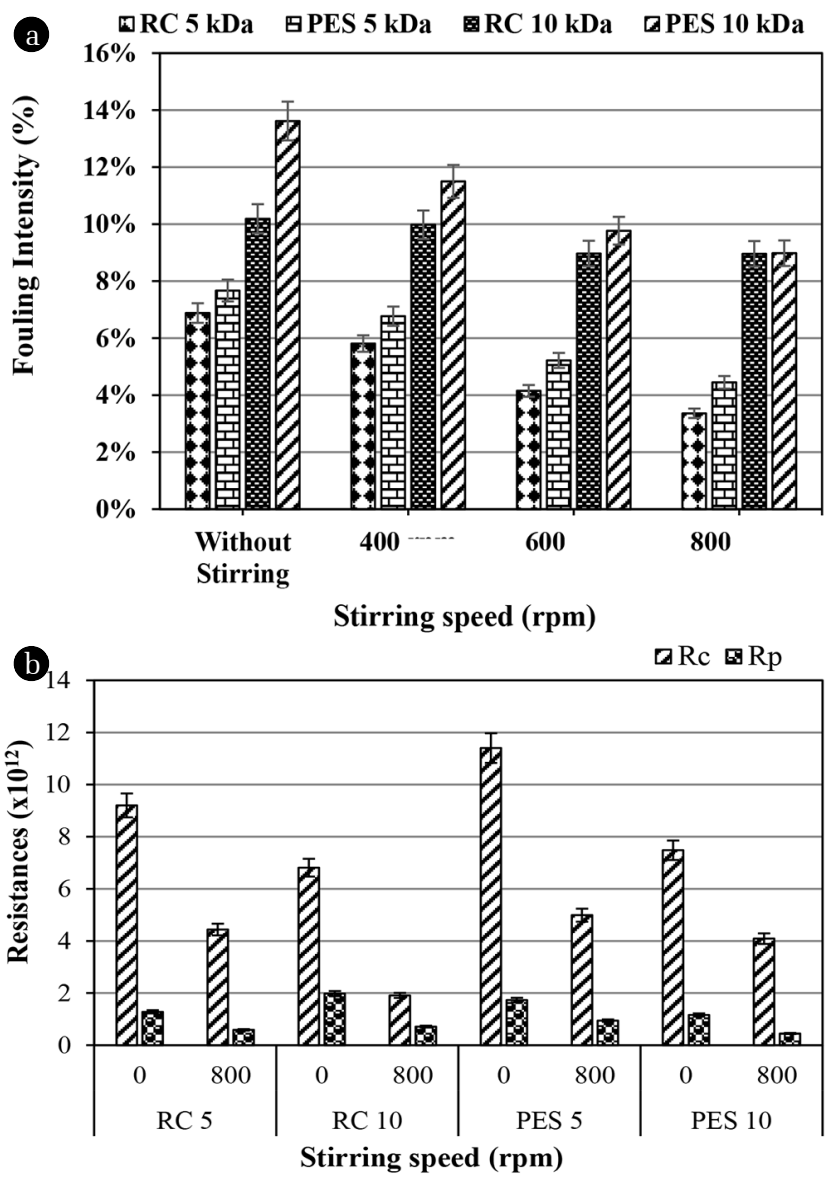

Fig. 5. Effect of stirring speed on membrane fouling: (a) fouling intensity (b) fouling resistance.
$9.2 \times 10^{12} \mathrm{~m}^{-1}$, respectively. In the absent of hydrodynamic effect, the gel layer will form as soon as the filtration started and become thicker over time. As pressure applied, some of the particles were pushed into the membrane pores resulted in more severe fouling.

Cake resistance greatly reduced at $800 \mathrm{rpm}$ for both $5 \mathrm{kDa} \mathrm{RC}$ and PES membrane which were $4.99 \times 10^{12} \mathrm{~m}^{-1}$ and $4.44 \times 10^{12}$ $\mathrm{m}^{-1}$, respectively. It is clearly expected that as stirring speed increases, the mass and thickness of each fouling layer should decrease, resulting in decreased filtration resistance. Similar trend was also observed for $10 \mathrm{kDa}$ RC and PES membrane, where pore blocking resistance consistently lower than cake resistance. For instance, pore blocking resistance and cake resistance value at $800 \mathrm{rpm}$ for $10 \mathrm{kDa}$ PES membrane were $0.76 \times 10^{12} \mathrm{~m}^{-1}$ and $4.05 \times 10^{12} \mathrm{~m}^{-1}$, respectively. Besides, the $10 \mathrm{kDa}$ membrane showed higher pore blocking resistance compared to $5 \mathrm{kDa}$ membrane. Some particles have the same order of magnitude as the range of membrane pore size, some of the small particles could easily reach the pores against the shear force. In contrast, if the pores are much smaller, the particles tend roll off the membrane surface under the shear force induced by hydrodynamic conditions rather than remaining immobilize in the pores [25].

\subsubsection{Effect of stirring speed on permeate quality}

From Fig. 6(a) dissolved solid concentration is highest in the absence of stirring effect because there is no hydrodynamic effect to sweep the particles away, thus, increased the deposition of cake layer on the membrane surface. The pore size of membrane played a significant role in removing dissolved solid. For all membranes, dissolved solid concentration of $5 \mathrm{kDa}$ membrane is lower than10 $\mathrm{kDa}$ membranes, which is due to the existence of a fouling layer developed. Particles in final discharge POME tend to develop gel layer on the membrane surface of tight membrane, this fouling layer acted as another filter layer that increased the resistance for organic matter to pass through [26].

When the solution stirred at $400 \mathrm{rpm}, 600 \mathrm{rpm}$ and $800 \mathrm{rpm}$, dissolved solid concentration decreased. For example for RC and PES membrane dissolved solid concentration reduced from 562 $\mathrm{mg} / \mathrm{L}$ to $543 \mathrm{mg} / \mathrm{L}$ and from $627 \mathrm{mg} / \mathrm{L}$ to $525 \mathrm{mg} / \mathrm{L}$, respectively, due to the effect of stirring speed that attributed to the increase in the shear rate, resulting in reduction of NOM accumulation at the membrane surface as previously discussed. In the other hand, for $10 \mathrm{kDa}$ membranes both PES and RC, at $800 \mathrm{rpm}$, dissolved solid concentration does not show significant reduction as dissolved solid only reduced from $620 \mathrm{mg} / \mathrm{L}$ to $618 \mathrm{mg} / \mathrm{L}$ and $607 \mathrm{mg} / \mathrm{L}$ to $597 \mathrm{mg} / \mathrm{L}$ for both RC and PES membrane, respectively. When the stirring speed is too high, it will sweep away the deposition of cake layer on the membrane surface, the particles in return to the solution moves parallel to the hydrodynamic movement, since the pore size of membrane are larger, dissolved particles will easily pass through the membrane [4].

As shown in Fig. 6(b), as the stirring speed increased, the turbidity concentration was decreased. For instance, turbidity for $5 \mathrm{kDa}$ PES membrane reduced from 1.98 NTU to 0.97 NTU. This is because by increasing speed, the hydrodynamic effect and shear stress were also increased which then returned back the accumulated compounds on the membrane surface back to the fluid [7]. The chances of the particles to pass through the membrane was lower as increased 
Table 2. Quality of Final Discharged, and Treated POME

\begin{tabular}{|c|c|c|c|c|c|c|c|}
\hline \multirow[b]{2}{*}{ Parameter } & \multirow[b]{2}{*}{$\begin{array}{c}\text { Final } \\
\text { discharged }\end{array}$} & \multicolumn{4}{|c|}{ Ultrafiltration treatment } & \multirow{2}{*}{$\begin{array}{c}\text { Final discharged limit } \\
\text { standard B } \\
\text { (Department of } \\
\text { environment, 2010) }\end{array}$} & \multirow[b]{2}{*}{$\begin{array}{l}\text { EPA Guideline for water } \\
\text { reuse standard } \\
(\mathbf{2 0 0 4 )}\end{array}$} \\
\hline & & $\begin{array}{c}5 \text { kDa } \\
\text { RC }\end{array}$ & $\begin{array}{l}5 \text { kDa } \\
\text { PES }\end{array}$ & $\begin{array}{c}10 \mathrm{kDa} \\
\mathrm{RC}\end{array}$ & $\begin{array}{c}10 \text { kDa } \\
\text { PES }\end{array}$ & & \\
\hline $\mathrm{pH}$ & 8.05 & 7.89 & 8.10 & 8.01 & 8.88 & $6.0-9.0$ & $6.0-9.0$ \\
\hline Dissolved solid (mg/L) & 890 & 541 & 538 & 613 & 596 & - & - \\
\hline Suspended solid (mg/L) & 43 & $<25$ & $<25$ & $<25$ & $<25$ & $\leq 50$ & $\leq 30$ \\
\hline $\mathrm{BOD}_{5}(\mathrm{mg} / \mathrm{L})$ & 97 & 33.3 & 27.7 & 66.3 & 58.1 & 50 & $\leq 30$ \\
\hline COD (mg/L) & 170.8 & 96 & 62.8 & 120.8 & 112.2 & 100 & - \\
\hline Turbidity (NTU) & 17.6 & 1.44 & 1.02 & 2.26 & 2.12 & - & - \\
\hline
\end{tabular}
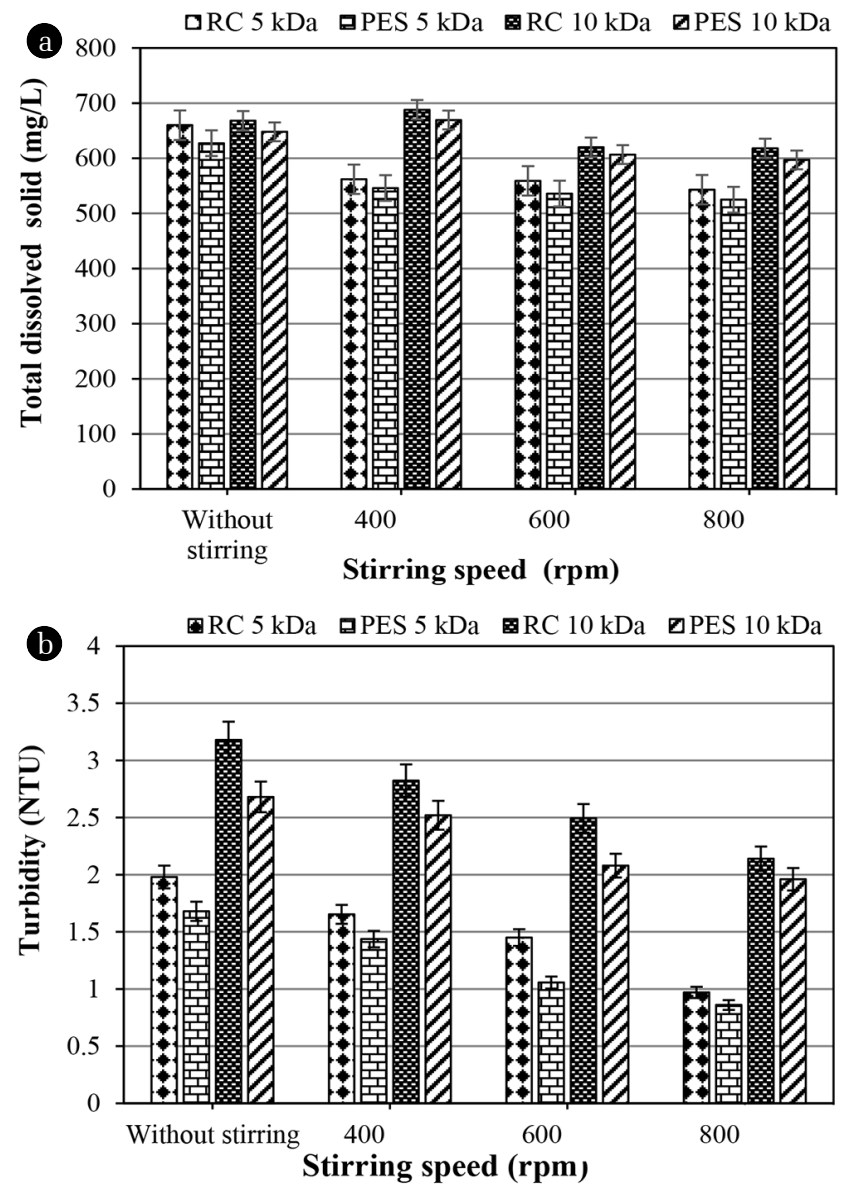

Fig. 6. Effect of stirring speed on (a) total dissolved solid (b) turbidity.

in hydrodynamic effect resulted in higher shear stress that reduced the formation of gel layer on the membrane surface. In the other hand, without the presence of stirring effect, the turbidity value is high. This is due to the fouling phenomenon. During filtration, gel layer continuously developed on the membrane surface over time, and the pressure applied during filtration might pushed the particles that accumulate on the membrane surface through the pores into the permeate sides.

Table 2 represent the quality of treated final discharged for all membrane at pressure 1.0 bar with stirring speed $600 \mathrm{rpm}$. At this condition, fouling resistance of those membranes was not too high compared to higher pressure, and showed good permeate quality. Thus, the permeate were further analyzed for COD and $\mathrm{BOD}_{5}$. As can be seen from the table, membrane with MWCO $5 \mathrm{kDa}$ showed better permeate quality compared to $10 \mathrm{kDa}$ membrane. This might due to the size of foulant particles were smaller than pore size of $10 \mathrm{kDa}$ membrane, thus, the particle were able to pass through the membrane. PES membrane showed better permeate quality than RC membrane, but slightly higher fouling compared to RC. Therefore, PES membrane with MWCO $5 \mathrm{kDa}$ showed the best permeate quality, beyond final discharged limit set by DOE and able to achieved water reuse standard from EPA guideline.

\section{Conclusions}

This experiment investigate the effect of pressure and stirring speed on the performance of ultrafiltration membrane in treating final discharged POME using two types of membrane, PES and RC with MWCO 5 and $10 \mathrm{kDa}$. Membranes performance were evaluated based on fouling resistance and permeate quality in terms of dissolved solid, turbidity, suspended solid, COD and $\mathrm{BOD}_{5}$. It can be concluded that:

i ) The best operation condition at 1 bar and stirring speed $600 \mathrm{rpm}$. At this condition, fouling resistance of those membranes were not too high compared to higher pressure, and showed good permeate quality.

ii) A dominant type of fouling is cake resistance. At any pressure and stirring speed, cake resistance was higher compared to pore blocking resistance, this might due to dead-end filtration modes, which induced cake layer as soon as filtration start.

iii) PES membrane with MWCO $5 \mathrm{kDa}$ showed the best permeate quality where the dissolved solid, turbidity, suspended solid, COD and $\mathrm{BOD}_{5}$ were $538 \mathrm{mg} / \mathrm{L}, 1.02 \mathrm{NTU},<25 \mathrm{mg} / \mathrm{L}, 27.7 \mathrm{mg} / \mathrm{L}$ and $62.8 \mathrm{mg} / \mathrm{L}$, respectively.

iv) Permeate from PES membrane successfully achieved water reuse standard provided by EPA guidelines in terms of $\mathrm{BOD}_{5}$ and suspended solid. With suitable type of membrane, UF were proved to be efficient in reclaiming water from final discharged POME. 


\section{References}

1. Ahmad AL, Ismail S, Bhatia S. Water recycling from palm oil mill effluent (POME) using membrane technology. Desalination 2003;157:87-95.

2. Mohammad AW, Ng CY, Lim YP, Ng GH. Ultrafiltration in food processing industry: Review on application, membrane fouling, and fouling control. Food Bioprocess Technol. 2012;5: 1143-1156.

3. Ahmaruzzaman M. Adsorption of phenolic compounds on low-cost adsorbents: A review. Adv. Colloid Interface Sci. 2008;143:48-67.

4. Ahmad AL, Sumathi S, Hameed BH. Residual oil and suspended solid removal using natural adsorbents chitosan, bentonite and activated carbon: A comparative study. Chem. Eng. J. 2005;108: 179-185.

5. Van Reis R, Zydney A. Membrane separations in biotechnology. Curr. Opin. Biotechnol. 2001;12:208-211.

6. Wu TY, Mohammad AW, Jahim JM, Anuar N. Palm oil mill effluent (POME) treatment and bioresources recovery using ultrafiltration membrane: Effect of pressure on membrane fouling. Biochem. Eng. J. 2007;35:309-317.

7. Azmi NS, Yunos KF. Wastewater treatment of palm oil mill effluent (POME) by ultrafiltration membrane separation technique coupled with adsorption treatment as pre-treatment. Agric. Agric. Sci. Procedia 2014;2:257-264.

8. Tardieu E, Grasmick A, Geaugey V, Manem J. Influence of hydrodynamics on fouling velocity in a recirculated MBR for wastewater treatment. J. Membr. Sci. 1999;156:131-140.

9. Ognier S, Wisniewski C, Grasmick A. Influence of macromolecule adsorption during filtration of a membrane bioreactor mixed liquor suspension. J. Membr. Sci. 2002;209:27-37.

10. Mirsaeedghazi H, Emam-Djomeh Z, Mousavi SM, Aroujalian A, Navidbakhsh M. Clarification of pomegranate juice by microfiltration with PVDF membranes. Desalination 2010;264:243-248.

11. Tansel B, Dizge N, Tansel IN. Analysis of high resolution flux data to characterize fouling profiles of membranes with different MWCO under different filtration modes. Sep. Purif. Technol. 2017;173:200-208.

12. Nourbakhsh H, Alemi A, Emam-Djomeh Z, Mirsaeedghazi H. Effect of processing parameters on fouling resistances during microfiltration of red plum and watermelon juices: A com- parative study. J. Food Sci. Technol. 2014;51:168-172.

13. Na J, Yonggang Z. The effect of humic acid on ultrafiltration membrane fouling. Energ. Procedia 2012;11:4821-4829.

14. Jun Z, Yang FL, Meng FG, Peng AN, Di WA. Comparison of membrane fouling during short-term filtration of aerobic granular sludge and activated sludge. J. Environ. Sci. 2007;19:1281-1286.

15. Hammer MJ. Water and wastewater technology. Singapore: Prentice Hall. 1986. p. 519.

16. Susanto H, Ulbricht M. Photografted thin polymer hydrogel layers on PES ultrafiltration membranes: Characterization, stability, and influence on separation performance. Langmuir 2007;23:7818-7830.

17. Puro L, Kallioinen M, Mänttäri M, Natarajan G, Cameron DC, Nyström M. Performance of RC and PES ultrafiltration membranes in filtration of pulp mill process waters. Desalination 2010;264:249-255.

18. Yorgun MS, Balcioglu IA, Saygin O. Performance comparison of ultrafiltration, nanofiltration and reverse osmosis on whey treatment. Desalination 2008;229:204-216.

19. Chollangi A, Hossain MM. Separation of proteins and lactose from dairy wastewater. Chem. Eng. Process. Process Intensification 2007;46:398-404.

20. Nakatsuka S, Michaels AS. Transport and separation of proteins by ultrafiltration through sorptive and non-sorptive membranes. J. Membr. Sci. 1992;69:189-211.

21. Boyd RF, Zydney AL. Sieving characteristics of multilayer ultrafiltration membranes. J. Membr. Sci. 1997;131:155-165.

22. Mohammadi T, Esmaeelifar A. Wastewater treatment using ultrafiltration at a vegetable oil factory. Desalination 2004;166: 329-337.

23. Kang SK, Choo KH. Use of MF and UF membranes for reclamation of glass industry wastewater containing colloidal clay and glass particles. J. Membr. Sci. 2003;223:89-103.

24. Lee N, Amy G, Croué JP, Buisson H. Morphological analyses of natural organic matter (NOM) fouling of low-pressure membranes (MF/UF). J. Membr. Sci. 2005;261:7-16.

25. Choi H, Zhang K, Dionysiou D, Oerther DB, Sorial GA. Influence of cross-flow velocity on membrane performance during filtration of biological. J. Membr. Sci. 2005;248:189-199

26. Mourad H, Martine MP. Analysis of deposit behaviour in crossflow microfiltration by means of thickness measurement. Chem. Eng. J. 2002;86:251-257. 